\title{
Eighty-Six Years in Iowa: The Memoir of Ada Mae Brown Brinton
}

\author{
edited by GLENDA RILEY
}

During most of her long and active life, Ada Mae Brown Brinton has been an avid diary-keeper. In 1977, she reviewed some of her large collection of diaries and searched her keen memory to produce a reminiscence that her family could share. Her engrossing story began in the late 1860s when her father, Thacher Brown, and her mother's family, the Farnum Hinksons, decided to relocate in Iowa.

Thacher Brown was the first of the group to migrate to Iowa land in 1868. In 1869, Farnum and Sabra Ann Hinkson purchased native sod land across the road from him in Adair County, Iowa. The Hinkson's elder daughter, Rhoannah, had met and become engaged to Brown in Lawrence, Massachusetts where she worked in the textile mills; as settlers in Iowa, Rhoannah and Thacher were married. In the years that followed, Thacher turned from farming to take up dairying and carpentry in Stuart, Iowa. This is where Ada was born on May 5, 1891.

In her early twenties Ada married Marion Brinton, the son of a local well-to-do farmer. Four children were born to Marion and Ada: Justine Eloise, born in 1916, died following an accident in 1918; Elaine Maxine, born in 1920; Everett Brown, born in 
1924, died of intestinal flu in 1925; and Eloise Mae, born in 1927.

Through thrifty practices and industrious effort, Marion and Ada made a comfortable living on their farm. In the sixtieth year of their marriage, Marion died on April 28, 1974. Shortly after her husband's death, Ada Brinton moved from their farm home to an apartment in Stuart; she currently resides in Iowa City. The publication of the abridged version of her reminiscences which follows was made possible by her kindness and cooperation. The complete manuscript is available at the Division of the State Historical Society in Iowa City. Special thanks also go to her daughter, Elaine Brinton Phair, for her help with the manuscript.

My father, Thacher Brown, of Morrill, Maine, and his friend, Morrison Sanborn, of Grafton County, New Hampshire, came West by train in the spring of 1868 . They stopped in Morrison, Illinois to see the Horace Hinkson family, formerly from New Hampshire. After a brief visit, my father, who was 23 , and Mr. Sanborn continued by train on to Guthrie Switch, later known as Menlo, which was as far as the railroad extended west at that time.

My father purchased a farm south of Menlo, most of which was on well-laying ground. It did have a small creek and timber on the north end. Water and timber were considered very essential. . . . Papa bought a team and necessary farming equipment with which he "broke" the southern part of the farm and planted crops that same spring. He built protection for his horses and then started to build a house.

In 1869, my maternal grandparents of Grafton County, near Canaan, New Hampshire, Farnum and Sabra Ann Hinkson, journeyed by train to Morrison, Illinois with their children: My Mother, Rhoannah, 21; teenage Adda; and younger brother Fred Oscar. They stayed with the before mentioned Horace Hinkson, brother of Farnum. There a team, wagon and supplies were purchased, and with them my grandfather and his son, Fred, proceeded on to Adair County, Iowa where my father 
was located. In due time my grandmother with the two girls traveled to Iowa by train.

Following are excerpts from a letter Mamma wrote May 30, 1870 to Aunt Ada Brown in Massachusetts:

Having good weather, the prairie is green, grass quite tall so people are cutting it for their horses. The flowers that grow here are lovely bright colors that make a pretty bouquet. " $\mathrm{T}$ " (Thacher) is breaking sod, hard work so we did not go to church. The Methodist minister preached. (Apparently denominations took turns.) The house is generally filled. They go and carry their babies. Sometimes there are over a dozen little bits of things. They look as if they should be at home. People are not at all proud. They do not stop for looks. They wear sunbonnets and big aprons to church. The men ride on a board put across the wagon if they are too poor to be able to have a spring seat, and the women sit down flat on the bottom of the wagon. That is the West! The people around here do not trouble themselves much to get acquainted with the Yankees, as they call us. . . .

Earlier, during the time my father was in Lawrence, Massachusetts, my mother was working in one of the large textile mills there. My father and mother met in Lawrence while attending the same Baptist Church. After coming to Iowa, they were married on Christmas day, 1869. My mother, Rhoannah Hinkson, was 21 and my father, Thacher Brown, was 24 . . .

My father was a hard working man-was said to remark that he could outwork any team. However, he broke his health doing so and had to give up farming. He then bought the dairy farm just east of Stuart where I was born and he began doing carpenter work. He had learned the carpenter trade from his Uncle Elisha Merriam in Lawrence, Massachusetts under whom he served his apprenticeship. ... .

The dairy Papa operated was a type conforming to that date. Milk was carried in 5 and 10 gallon cans in a covered fourwheel wagon drawn by one horse. There were regular customers. When a hand bell was rung in front of a house, the customer would bring out containers and the milk was poured into either a pint or quart tin measure according to the amount 


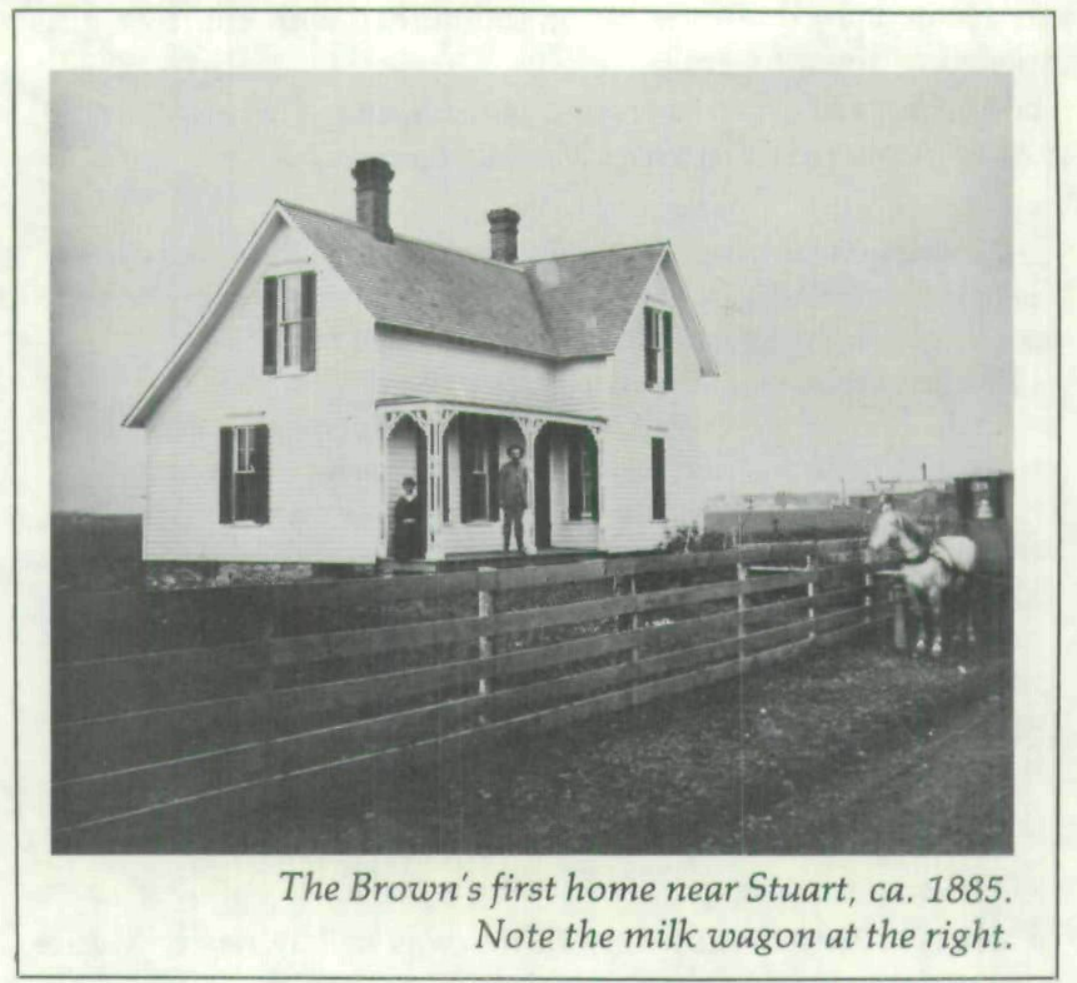

desired. Milk tickets were sold in advance in \$1.00 amountsred printed tickets for quarts and green for pints.

The dairy farm was sold in 1893 or 1894 . In ' 94 my parents, sister Luella and I went "back east" to visit relatives and attend a Brown family reunion. ... .

After selling the dairy farm and the trip "back east" in 1894, my father built a nice cottage of $1 \frac{1}{2}$ stories, plus a full basement. This was located out "on the hill" on Nassau Street, west of the business part of town. . . . Those of us who lived out "on the hill," as it was called, were sort of set apart from the rest of the townspeople, for there were no houses connecting that area for many years. . . . Upon moving out "on the hill" my father continued with a small dairy - he usually had three to four cows. It was my job to deliver the milk. We had a faithful driving horse by the name of "Fannie." She was hitched to an open buggy. Fannie knew the route as well as I did. When in a block 
where there were three or four houses to which I was to deliver -I carried the bottles in a heavy wire container which held eight bottles and left the bottles of milk in exchange for empty ones with tickets-and as I proceeded down the block Fannie walked along the street without any instruction, ready to pick me up at the last house. While this milk business continued it meant work for my mother to keep the bottles clean and filled. Due to the fact that my father always kept only Jersey or Guernsey cows, our customers were among the people who could afford and preferred this quality of milk. I came to know these families personally (many remained good friends the rest of their lives), as new people were seldom added to the list and the route was confined to a small area-three or four blocks in the central part of the town-as the quantity of milk was limited.

My parents attended church regularly and I was brought up to do so. In my teenage years this required five services a day on Sundays: Sunday School, Morning Service, Junior League in the afternoon as a teacher, Epworth League in the early evening followed by the Evening Church Service. Each year Evangelistic services were usually conducted for a week to ten days in the church by an outside evangelist and a "music leader." I accepted Christ during one of these meetings, was baptized and joined the Methodist Church on August 6, 1906.

As a young child I was "entertained" in various ways during church services. I remember lying in the pew with my head on my mother's knees so as to watch the glitter of many spangles on the beautiful chandelier which was hung from the center of the high ceiling of our church. I also listened to the ticking of my mother's watch when she would say, "Listen to the little boy chopping wood." In the summer she carried a fan which folded completely out of sight into the handle case. Upon pushing a slide button the fan would open out into a fluted circle with handle - that fascinated me. Another form of entertainment was provided by my mother's allowing me to try on her mittsthese were a form of gloves used in summer, made of knitted silk without fingers, open beyond the knuckles. . . .

My parents were loyal church workers. My mother was President of the Ladies Aid Society for ten years. The Ladies Aid met 
every two weeks in homes and indeed they did work! They raised money by piecing quilt blocks and then quilting them, by tying comforters, tearing and sewing carpet rags, making aprons and sunbonnets and other wearing apparel. Mamma and Lue made all of the fancy sunbonnets which became very popular. They took special orders as to color, for the bonnets were white on the outside with a solid color underneath. The crown was machine stitched with rows of stitching about onefourth inch apart. . . . The Ladies Aid Society at one time sold vanilla and lemon extract which came from a company in gallon jugs. The jugs were kept in our basement and Mamma transferred the extract into glass bottles and labeled them with proper stickers. I also remember about a large Scripture Cake being made one time in a new dish pan. The recipe was typed and given with the purchase of a piece of the cake. All of the ingredients of the cake had been mentioned in the Bible.

In our church there were two special programs each year in which youngsters took part and for which much preparation was made-Children's Day, the second Sunday of June, and the Christmas Program, always given on Christmas Eve. I served on committees for these programs in my teen years and know what a lot of patience and time is required as there were always some children who were hard to restrain. The programs were made up of Sunday School individuals and classes singing, speaking pieces, and performing drills. ... .

For Christmas there was always a large evergreen tree decorated by tinsel and lights. At the close of the program Santa Claus would appear from the entrance to the auditorium causing great excitement by his costume and chatter. At the time of my earliest recollection presents also were hung on the tree. The packages were labeled for the smaller children (presumably from their parents). The names were called out by Santa and specified helpers delivered the packages. I well remember a large beautifully dressed doll hanging rather high on a branch. Naturally each little girl hoped the doll might be hers. This caused envy and disappointment to such a degree that these gifts were discontinued. Instead, cute little paper boxes filled with candy and nuts were given to each child from the teacher of each class. These classes of younger children were called for- 
ward, one at a time, and the boxes were handed out. Then the classes of older children were called and each child received an orange or a polished apple.

There were always evening church services in all of the churches in my day. A large tree grew on the outer edge of the sidewalk almost directly in front of the Methodist Church. Some of the young fellows congregated under the tree to wait for girls to come from the evening service. It must have been too handy as it was cut down eventually!

At four I started my school experiences as a first grader at Whittier School House (West School). The first and second grades were in the basement in a room which was halfway under ground with tall windows of eight panes. We entered the basement through a one-story wooden-type building at the center of the brick school. This covered the stairway leading down. Then to the east of this wooden structure was a wide cement outside stairway with banisters which led up to the double doors opening into a hallway. In good weather scholars lined up in two rows and at a signal given by the teacher in charge who was standing in the doorway we marched up the stairs. ... There was a large playground to the south of the building and wooden walks led to two outhouses, one for girls and one for boys, and each divided into two separate compartments. There was a well with a pump in the northwest area of the front yard. Walks were across the north and west sides of the grounds with tall soft maple trees on these sides.

I went into High School at twelve years of age, which was too young. At that time there was an assembly room where Freshman, Sophomore, Junior and Senior year students did their studying and from which the students marched out to appointed classrooms as the piano was played. School began at nine o'clock with "chapel." At this time Scripture was read by faculty members, the Lord's Prayer was recited by faculty and students and then there was a singing session. The songs (not popular music) were openly requested by the students. On one occasion the Principal, a man greatly disliked, in the process of correcting one of the big boys in the assembly room, got into an awful scrap. The boy was knocked on the floor on his back and the Principal was choking him until he was getting blue in the face. Some girls 
cried and ran from the room, others screamed, whereupon some of the other boys pulled the Principal off.

I did not go to school beyond the middle of my junior year. My big handicap was algebra. I had gotten a poor start in the subject my Freshman year and was having to repeat second year algebra in my Junior year plus the regular Junior year studies. I was discouraged and at Christmas time I got a clerking job in the J. B. Grove Store and quit school. . . . Later I regretted that I was allowed to quit, but it was not an uncommon thing to do at that time.

I did continue to clerk on Saturdays and on call until eventually I became a full-time clerk. I always liked it, learned a great deal and knew women from far and near. The store drew trade from other towns, many coming on passenger trains which were then available.

For a number of years "Bates Hall" was the location of all entertainment features [in Stuart]. That was in the second story of the building occupied by the George Ryan Dry Goods Store. The Reverend Billy Sunday conducted some meetings in Bates Hall. There were musicals and public gatherings of all kinds there. In observance of Lincoln's birthday a program was given in Bates Hall and I spoke the poem which was said to have been Lincoln's favorite, "Why Should the Spirit of Mortal Be Proud?" In addition I sang in an operetta there, sang a solo for a high school graduation, our Stuart Quartette (of which I was a member) participated in a musical there and I was in a play. The Country Club put on a dandy play at Bates Hall-the play was repeated because it was so well accepted. A traveling stock company appeared at Bates Hall, producing a different play every two weeks. A Lecture Course, consisting of varied high-class entertainment over a period of three or four weeks in the wintertime, was held at either Bates Hall or the High School Assembly Room.

There were some very cold winters. .... Everyone wore warm knit long-sleeved and long-legged underwear either plain cotton, fleece lined or wool. Feminine attire included long stockings, summer and winter, usually two petticoats which were starched and worn under light-weight dresses in the summer. (My mother knit fancy stitched underskirts for us for 


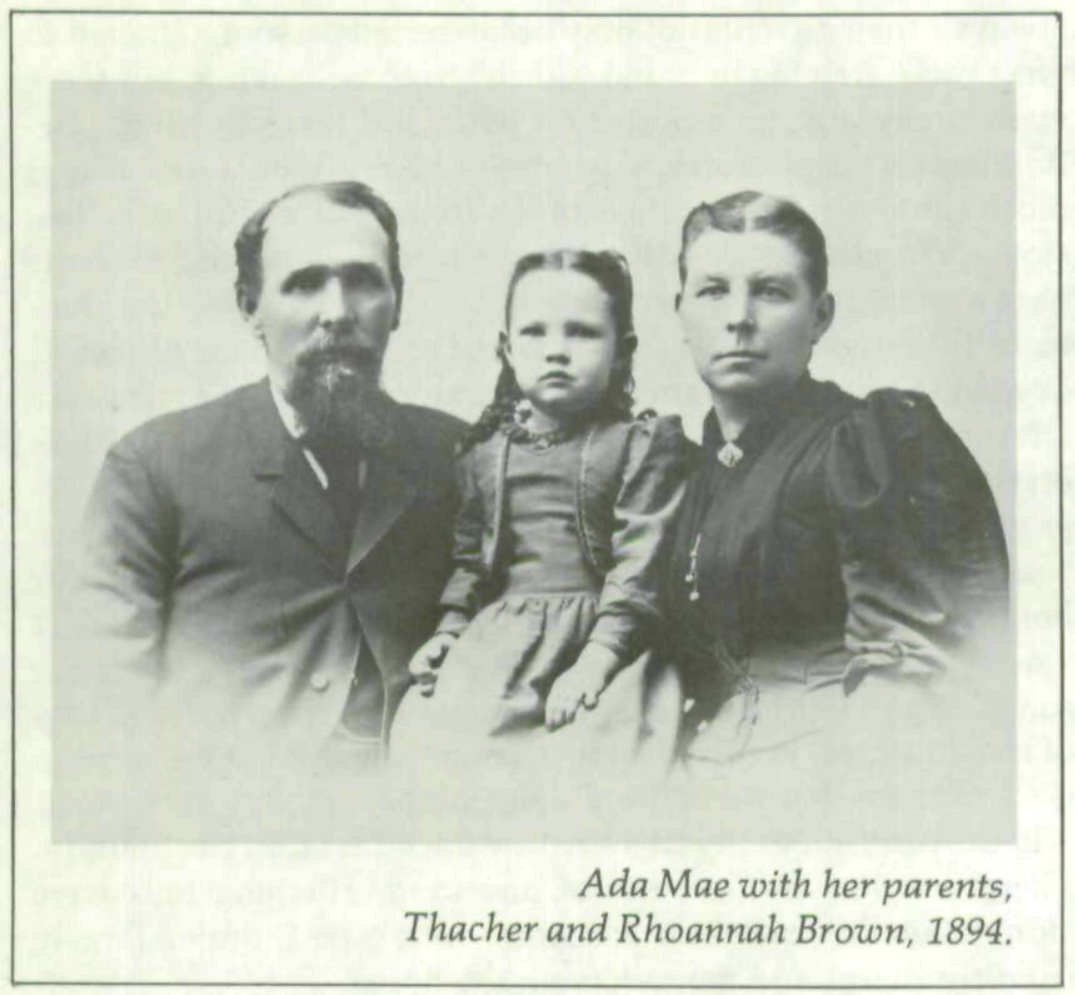

winter wear.) Remember, we rode in open conveyances and in summer there was no air conditioning. In the winter soapstones, hot water in jugs, heavy horse blankets and buffalo robes were used extensively when riding. " Buffalo robes" were originally made from tanned hides of buffalo, later from hides of cattle or horses.

In my years at home with my parents we had feather beds on our beds in the winter months. These were ticking filled with soft feathers from duck or goose breasts. It was the most wonderful feeling to sink into them and keep warm. They were somewhat lumpy. When making the bed, my mother used a wooden yardstick to even the top so that it would be perfectly smooth.

The arrival and departure of passenger trains at depots was

${ }^{1}$ Soapstone received this name because it feels somewhat like soap. Technically it is called steatite and is used for griddles, hearths, and insulation. 
always a major event, not only of interested persons gathered to greet those arriving or to bid "adieu" to those leaving, but there was usually a news reporter on hand and there were idle bystanders on the platform. The interior of small town depots was much the same. In the center of the room was a tall pot-bellied stove. Wooden benches with curved backs and smooth seats were around the perimeter of the room. I can still hear the chatter of the telegraph keys as they ticked endlessly in the office. At Division Centers the trains took on water and coal. Stuart was a Division Center. It was interesting to see the heavy hand trucks on the depot platforms. The trucks were wheeled out for baggage, express and mail sacks. In later years mail bags were suspended at a certain spot and as the train passed a long heavy hook reached out and pulled the bag into the mail car. There was also a train, the Guthrie Center Branch, which made the round trip to Guthrie Center each day. There were also plenty of freight trains. We lived a block from the track but we were so used to them that the noise did not bother. . . .

In the early 1900 s Stuart's streets were either dusty or muddy. There was no solid ground of any kind. Hitching rails were along Main Street. Flies in the stores were a pest, drawn largely from the sweat and manure from the horses.

I was young when I learned to ride horseback, having a nice sized riding horse, larger than a shetland pony, which I greatly enjoyed. . . . At one time in my career I had a tailored tancolored riding outfit made with a full-length divided skirt. . . . All of my youth I had horseback rides before breakfast as my father always got up at 4 a.m. to do chores and would bridle and saddle my horse in readiness for me. He continued to do this as long as I was home.

In the winter, with sufficient snow, sleighs and bobsleds were used extensively. Nothing can ever replace the pleasure of slipping smoothly over the snow. An added pleasure was to hear bells and chimes attached to the harness. My father had a long string of bells about the size of golf balls which were fastened around the body of the horse. Marion [her fiancé] had chimes the size of baseballs which were fastened on a leather piece. At times, of course, there were "spills" from the sleighs and bob- 
sleds, either purposely or otherwise, but the falls were cushioned by snowdrifts.

In our church two special services were often the same Sunday: The School Baccalaureate in the evening and the Memorial in the morning. At the Memorial service the members of the "G.A.R." 2 followed by Veterans of the Spanish American War and their auxiliaries marched down the front aisle carrying flags and were seated in the center seats. It was an impressive sight as I recall to see the white-haired Civil War soliders. Their auxiliary was called "Woman's Relief Corps." ${ }^{3}$ There was a window in the Methodist Church carrying symbols of the two Civil War organizations.

On the 31st of May, Memorial Day, there used to be celebrations held at North Oak Grove Cemetery. The G.A.R. soldiers rode out from town while people walked. A band led the march. There was a small bandstand in the cemetery situated with rolling ground to the west where people sat on the ground for the program. Usually the band played and a speaker gave a suitable address. One year our "Stuart Quartette" (I was one of the singers) sang a couple of songs as a part of the program.

The Fourth of July used to be really celebrated. I always had some firecrackers which were fun to set off. My father showed me how to place one under an empty tin can to make a big noise. Also, he put a couple of long nails in the end of a lightweight pole of some kind in which a firecracker was placed as soon as it was lighted and the pole raised in the air. It seemed a safe way to shoot off the larger firecrackers. ... .

Our house was thoroughly cleaned each Spring and Fall. Carpets were taken outside and either thrown over the clothes line or put on the grass where a carpet beater was used to remove the dust. The dining room in my parents' home was covered by rag carpet. .... It was made from clothing discarded in our family. The clothing was washed and torn into strips which

${ }^{2}$ GAR stands for the Grand Army of the Republic, an organization of those who served on the side of the North during the Civil War.

${ }^{3}$ There were many women's relief groups established during the Civil War to provide clothing, bandages, food, and nursing aid to the soldiers. Annie Turner Wittenmyer, Ann E. Harlan, and Amelia Bloomer were a few of the more well-known leaders of such groups in Iowa. 
were sewed end to end, rolled into balls and sent to someone who had a loom on which to weave any length desired. It was fun to try to discover some former dress. The width of the woven strips was 36 inches, so the strips were sewed together for the width required for the room.

Marion and I were engaged in 1913. In the fall of 1914 preparations were made for the building of a house on the farm owned by Marion two miles west of Stuart up on a high spot from which the view of the countryside was wonderful in all directions. Marion bought books of houseplans and we discussed plans in them. Papa was consulted as well as Marion's father. Rock for the foundation was laid by Roy Morrison, a reliable mason. The floor of cement covered the entire basement under all of the house with a garage under the large front porch. Papa and a contractor in Stuart built the house. Somewhere Father Brinton had seen finishing casings used in framing doors and windows which were different from any used in our vicinity. They had a smooth curved exterior. He ordered the lumber from a Minnesota lumber company. I was most grateful in all future years when cleaning for this extra effort on his part, for other casements usually had ridges which were dirt catchers. White pine was used in the house. . . .

Our wedding was in my parents' home on December 9, 1914. We invited only our immediate families. . . . The wedding was at "high noon" followed by a very nice luncheon. The second course of the luncheon was a slice of brick ice cream with a lavender bell in the center . . . and angel food cake plus fruit cake which had been made from a recipe used at weddings in Mamma's family. My wedding dress was silk crepe-dainty flowers on a deep purple background. I had a cream colored chiffon shoulder cape trimmed by deep cream lace on the sleeves. Marion wore a vested dark blue suit.

The weather was good but later snowflakes fell on us as Bert Chittick [Ada's brother-in-law] drove us in an open buggy to the railroad depot to take the train, which came shortly after two o'clock, to Des Moines. We stayed at the Savery Hotel. The great evangelist, Billy Sunday, was holding meetings not far 
from the hotel. We attended, and for the first time we heard the song, "Brighten the Corner Where You Are" and never forgot the tune and the words. ... .

In Omaha we looked for furniture and purchased a brown leather covered large chair..... Among other gifts, Father Brinton had slipped me a $\$ 100$ bill. This was spent for the chair. We received very useful gifts, many of which were used all our lives. ... .

Our years were busy happy ones. For years after moving to the country I still took part in various activities in town. I often drove to Lue's and to my parents' home. In fact I was away in the afternoon almost daily. Marion always inquired at noon if I had plans to go. If so, he harnessed a horse and left it hitched to the buggy all ready for me. After we had a car he made sure all was in readiness for me.

Marion had been a charter member of the Stuart Country Club. ${ }^{4}$ I was initiated. This club was a most worthwhile organization and the leading one of the vicinity. Most of the time the members were farm couples within the neighborhood. We were active for 55 years. Our topics and discussions were based on those of leading issues concerning the betterment of our homes, of our country and naturally concerning farm improvement. We had many good times together, meeting once a month in our homes. At no time did we play cards. We often had prominent outside speakers. At one time Henry A. Wallace, who later became Secretary of Agriculture and then Vice President of the United States, was our speaker. ... .

Corn picking was done by hand, throwing the husked ears into the wagon as a reliable team kept slowly walking ahead without interruption except to be turned at the end of the row. Marion picked 100 bushels a day, much above the average. At noon and at night the corn was shoveled by scoop into the corn crib. Marion was in the field by daybreak. That meant husking mittens getting soaked by the frost on the corn husks. Our kitchen range would have mittens laid on the oven door to dry out during that season of the year. As time went on Marion's third finger on his right hand became somewhat curved which

${ }^{4}$ This organization was more like the Grange in its intent and goals rather than being like country clubs of today. 
he always said was caused by his grabbing the ear of corn off the stalk with a brass husking peg worn on his finger.

Sowing oats was accomplished by loading the seed into the wagon box with a mechanism on the end which could be adjusted as to the amount of seed allowed to go through and be evenly spread over a certain area. This was the only farming operation in which I helped. Marion drove the team (later, the tractor) while I rode in the wagon box to see that enough grain was being pushed into the spreader-not a hard job!

During the years when our family was growing up and we had hired men I did a great deal of canning of fruit, vegetables and meat-chicken, beef and pork which we raised. Thus we did not have a problem of going to the butcher shop in town except when large roasts were required to feed the twenty or more threshers, plus the women who helped prepare the food. Breads, pies and cakes were baked at home, of course. In reading my diary of 1935, I came upon the following menu for threshers at our home that year: Mashed potatoes, beef roast, gravy, ham loaf, baked kidney beans, creamed corn, homemade cottage cheese, dill pickles, apples cooked with lemons, plum jelly, fresh rolls and butter (both homemade), two kinds of cake, homemade ice cream, iced tea, coffee and cream.

During my early days on the farm and during World War I, everyone was making their own soap for laundry work. Of course on the farm where home butchering was done it was an easy thing to have the required grease. Tallow was melted along with hog fat-in fact the tallow presumably made better soap, but it was not used alone. ${ }^{5} \mathrm{I}$ am going to record a recipe which should produce good results: $5 \mathrm{lbs}$. grease, $5 \mathrm{qt}$. of cold soft water, 1 cup lye, $1 / 2$ cup ammonia, 1/2 cup Perfex can also be dissolved and added. Dissolve lye in a little soft water. Mix with all ingredients. Stir until creamy and it thickens. Pour mixture to set into enamel, stoneware, or a wooden box lined with white cloth. (We used the latter.) Don't get the mixture on hands until in hard soap stage.

The job of washing clothes was quite different from nowa-

\footnotetext{
${ }^{5}$ Tallow is a whitish, tasteless solid or hard fat obtained from cattle, sheep, etc., used to make candles and soap. Some women preferred to make a separ-
} 


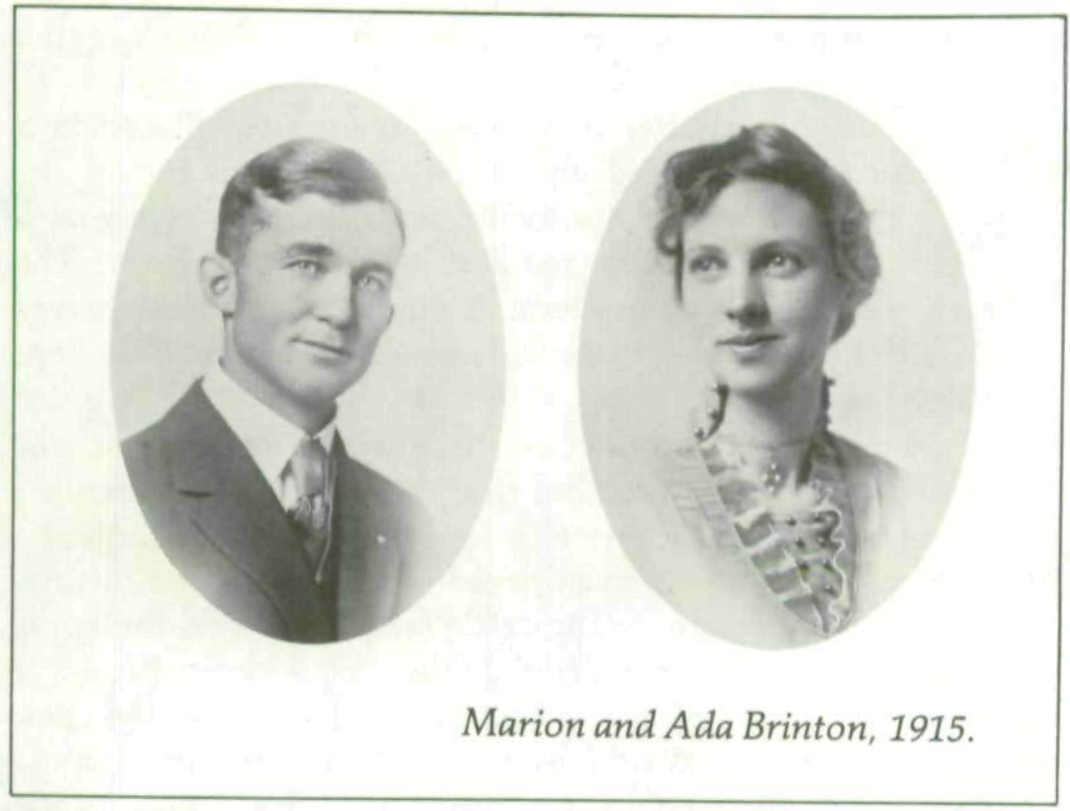

days! In town my Mother used a copper boiler in which to boil white clothes and to heat the wash water. At least she had good facilities for those days. The pump was outside the door of the cement floored room in the basement which opened up at ground level. We had a stove down there, so water didn't have to be carried far. If the water was hard, some lye was put into the boiler of water which brought a thick foam up on the top. This foam was dipped off. Often some bluing was added. The washing machine was hand propelled. On the farm my machine was run by a small gasoline motor until we had electricity-I also had a double tub machine. Time was saved with that as one tub could be used for rinsing. Later I had an enamel lined electric machine and finally we had a modern washer and dryer installed on our back porch. We always had soft water in our entire water system on the farm. Our large cistern filled from gutters around the roof of the house. Water was heated by pipes run-

ate batch of tallow soap for personal hygiene along with the stronger lye and grease based soap used for laundry. Lye is a rather harsh alkaline solution obtained by leaching (slowly running water through) wood ashes. 
ning through the cook stove and stored in a tank back of the stove.

For refrigeration, butter and sweet cream were placed in a bucket which was lowered on a rope down to the top of the water in the well. When our house was built, Marion had a hole, perhaps ten feet deep, made in the basement floor. The hole was cemented like a cistern. A dumb waiter with shelves was lowered and raised by a small chain on a pulley. This kept food reasonably cool.

The principal fuel for our cook stove during the summer was cobs, as they made a quick hot fire, though frequent refueling was necessary. It was a chore to keep enough cobs available. Many were picked up from hog feed lots. These had a distinctive odor not appreciated! The cattle feed bunks and the horse feed boxes in the barn provided the other cob sources. Wood, if available around the place, and coal were also used in the cook stove. In our early days there were two or three small spots north of town where coal was mined, but it was a poor grade (too much slate or too soft) and choked up the stove and pipes.

Stuart had Chautauqua for a number of years. ${ }^{6}$ This was held in a large tent on the grounds of the West School for a week in August and provided entertainment for both afternoon and evening shows. This was well attended and people came from Menlo and Dexter, as well as the Stuart community, to enjoy the programs. The advent of radio spoiled the Chautauquas.

Saturday night was the time when farmers particularly "went to town." Chores and supper were hurried up as it was important to park one's car in a favorable spot so that after grocery buying the car could be used from which to watch others going by. Among other errands the men would drop in at the barber shop to wait for a haircut and shave (in many cases decidedly changing their appearance for the better). The younger members of a family located their friends and spent a little money on confections to their liking and walked up and down the street. If fortunate enough to have arrived in town for the early picture show, the young people often went there and afterwards knew

${ }^{\circ}$ Chautauquas were public assemblies for the purpose of education and entertainment by lectures, concerts, etc. 
where to find their parents "passing the time of day" with a friend or two. I am sorry to say that we often saw those who had taken "a drink" or two too many at one of the Beer Parlors or the Pool Hall. Some unfortunate hired men had little left in their pockets after a Saturday night in town.

We had some exceedingly rough years in the 1930's during the Depression and Drought. We had to count our pennies, for prices for farm products touched bottom. Many supposedly well-to-do people lost all they possessed. In most cases home farms were mortgaged in order to buy more land. Then, when prices for farm products dropped, the income wouldn't cover the indebtedness and all was lost. One of our good neighbor friends had a few days left before foreclosure. We were told of his determination not to lose. He took an unprecedented chance and called President Franklin D. Roosevelt personally, stating his dilemma. Our friend was told that help would come, and the bank was ordered not to proceed with its intended foreclosure. . . . We found help from an old friend who was one of the few people who had money. He loaned us what was needed and insisted that if we could not pay the interest when it became due that we were not to worry, just pay when possible.

Of course we went through some hard times-the Depression and Drought. We tried to spend our money wisely and therefore we enjoyed many extras that came within our lifetime. We did not use tobacco or liquor. We suffered the loss of two children. But were blessed by two very precious girls whom we tried to guide in the right ways of life, and they did not disappoint us.

We lost Marion on April 28, 1974 at the Dexter, Iowa Hospital. I had no thought of leaving the home Marion and I had enjoyed for close to sixty years but this was suddenly changed by events on October 9, 1974. ${ }^{7}$ Following this experience, my family insisted that I could no longer live in my home on the farm. By great luck there was a comfortable one-bedroom apartment vacant in Stuart's Retirement Apartments and I have lived here since October, 1974. . . .

${ }^{7}$ Brinton was robbed and brutally threatened by two masked intruders. 
Copyright of Annals of Iowa is the property of State of Iowa, by \& through the State Historical Society of Iowa and its content may not be copied or emailed to multiple sites or posted to a listserv without the copyright holder's express written permission. However, users may print, download, or email articles for individual use. 